\title{
EFFECTS OF DIFFERENT KINDS OF SEWAGE SLUDGE AMENDMENT ON URBAN LAWN GRASSES
}

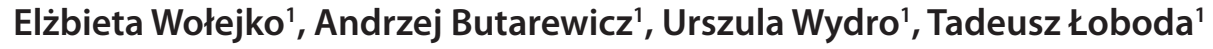 \\ 1 Division of Sanitary Biology and Biotechnology, Faculty of Civil and Environmental Engineering, Bialystok \\ University of Technology, 45d Wiejska Str., 15-351 Białystok, Poland, e-mail: e.wolejko@pb.edu.pl
}

Received: 2014.08.14

Accepted: 2014.10.17

Published: 2015.01.02

\begin{abstract}
The paper presents the results of research on the use of sewage sludge from the municipal sewage treatment plant in Białystok for fertilization of urban lawns. To fertilize the ground two types of deposits were used: stabilized sludge after the dewatering process in the press and granular sludge after drying in the sludge dryer. Two doses of sludge were used -5 and $10 \mathrm{~kg} / \mathrm{m}^{2}$. Effective microorganisms (EM) were added to the test plots. Both doses of the applied sewage sludge contributed significantly to the growth of grass biomass. Aboveground biomass of the plants was significantly correlated with the concentration of $\mathrm{Cd}, \mathrm{Cu}, \mathrm{Pb}$ and $\mathrm{Zn}$ in the surface layer of the soil. The addition of EM to soil containing the dewatered sludge from the press reduced significantly the content of heavy metals in the soil, as opposed to the sludge in a form of granules with addition of EM, which contributed to the increase of their concentration in the soil.
\end{abstract}

Keywords: sewage sludge, soil, heavy metals, effective microorganisms.

\section{INTRODUCTION}

Sewage sludge is an essential product of wastewater treatment processes. Sludge extracted from wastewater is a complex organic-mineral substance, composed mainly of carbon, hydrogen, oxygen, nitrogen, sulfur, and chlorine [Wilk, Wolańczyk 2008].

Most of the sludge produced in municipal sewage treatment plants in Poland should be designed for natural use, including use in agriculture. The only obstacle to use sludge in agriculture on a large scale may be the presence of heavy metals and pathogenic organisms in it. Therefore, the preferred direction of the management of sediment should be the use of such processes, which would allow for the inactivation of pathogenic microorganisms and heavy metals [Butarewicz 2013]. If this condition is met, settlements are an excellent product to be used in nature, which makes it possible to recycle valuable components, such as organic matter, nitrogen, phosphorus and other nutrients for plants. Fertilization with stabilized sludge helps to increase humus in soil, as well as to improve its quality. Fertilization deposits may help to increase the yield of various crops, such as cereals, vegetables, trees and shrubs, thus influencing the landscape [Pathak et al. 2009]. However, the potential benefits of adding sewage sludge to soils are balanced by the risk of increasing the content of heavy metals in soil. The conditions for the application of sewage sludge into soil are regulated by EC Directive 86/278/EEC and are based on heavy metal content in both soil and sludge [Paz-Ferreiro et al. 2012].

The heavy metals in sewage sludge are present in dissolved, precipitated and co-precipitated forms with metal oxides or adsorbed on the particles of biological remains [Alvarez et al. 2002]. According to Weiner and Matthews [2003], metals can be in a form of oxides, hydroxides, sulfides, sulfates, phosphates, silicates, organic connections in a form of complexes with humic compounds and complex sugars. These changes affect the diversity of chemical forms of heavy metals accumulated in sewage sludge. However, some mobile forms can penetrate from the sediment to the soil environment [Alvarez et al. 2002; Weiner, 
Matthews 2003; Skoczko, Piekutin 2014]. The intensity and magnitude of soil and plants contamination with heavy metals often depend not only on local factors. A major source of trace elements deposited on the surface of the soil and plants is the spread of pollutants over long distances [Kabata-Pendias, Pendias 1999].

Green city areas, including lawns, have various kinds of functions. On the one hand, well cared lawns enhance the aesthetic value of the city, on the other hand, they play a phytoremediation role, both for air and soil [Gawroński 2009]. For the effective phytoremediation plants should be characterized by high resistance to difficult environmental conditions, to have the ability to accumulate xenobiotics from the soil as well as to rapid growth and high dry mass production. Grasses are characterized by high phytoremediation potential [Singh et al. 2009]. According to Gawroński [2009], grasses in urban areas can fulfill the above requirements when they have good conditions for rapid growth and high dry mass production. For this purpose, sewage sludge may be used as a substitute for fertilizers, and at the same time effective microorganisms (EM) could be used to stimulate the growth of grasses. EM has a wide application in the field of agriculture, natural farming, livestock, gardening, composting and bioremediation. This consortium of microorganisms accelerates breakdown of proteins, sugars, fats and fibers, and thus, promotes rapid organic matter decomposition. EM works in two primary ways: competitive exclusion of harmful microorganisms and production of beneficial products such as enzymes, organic acids, amino acids, hormones and antioxidants that improve conditions of the environment [Khaliq et al. 2006].

The aim of this study was to examine the applicability of two different types of sewage sludge from the Municipal Wastewater Treatment Plant in Bialystok: dehydrated sludge from the press and dried in the form of granules to the turf lawns. At the same time the possibility of using EM to stimulate the decomposition of sludge and grass growth was also examined.

\section{MATERIALS AND METHODS}

The study was conducted on the campus of the Białystok University of Technology (Białystok, Wiejska Str. 45). The experiment was established in April 2012 in a randomized block design (on plots of $2 \mathrm{~m}^{2}$ ). The plots were located in the green belt along the internal road. The surface of the research was divided into three blocks with an area of $20 \mathrm{~m}^{2}$ each, constituting replicates. To fertilize the studied soil two different types of sewage sludge from the sewage treatment plant in Białystok were used: dewatered sludge after press and dried in the form of pellets. Prior to the use of sludge both types of sludge were tested according to the Regulation of the Minister of Environment of 13 July 2010 on municipal sewage sludge (Journal of Laws of 2010 No 137 item. 924). The analyses of Salmonella genus were carried out on EPA Method 1682: Salmonella in Sewage Sludge (Biosolids) by Modified Semisolid RappaportVassiliadis (MSRV) Medium. The parasitological tests were carried out in accordance with Polish Standard PN-Z-19000-4 and recommended by US EPA.

Two doses of dehydrated sludge 5 and 10 $\mathrm{kg} / \mathrm{m}^{2}$ and two doses of the granular sludge, 1.5 and $3 \mathrm{~kg} / \mathrm{m}^{2}$, with or without $51 \mathrm{EM}$ per square meter were used on each experimental field. EM were from Greenland Technology EM, currently the only licensed manufacturer of EM in Poland. There were also experimental fields without sewage sludge (control).

In the experiment grass mixture Roadside from Barenbrug was used, which contains 32\% of Lolium perenne cv. Barmedia, 5\% of Poa pratensis cv. Baron, $52 \%$ of Festuca rubra rubra cv. Barustic, $5 \%$ of Festuca rubra commutata cv. Bardiva (BE) and $6 \%$ of Festuca rubra commutata cv. Bardiva (NL).

Due to adverse weather conditions the grass mixture was sown in an amount of $30 \mathrm{~g}$ per plot on 29 April 2012. On 4 June 2012, the first harvest was done. The second harvest was on 1 July 2012. In September 2012 samples of soil (0-20 $\mathrm{cm})$ were collected. Heavy metals concentrations in soils fertilized with sewage sludge and in plant material were determined using Atomic Absorption Spectrometry AAS. The samples of soil were mineralized in temperature at about $450^{\circ} \mathrm{C}$ and remains were dissolved in aqua regia (3:1 mixture $\mathrm{HCl}$ and $\mathrm{HNO}_{3}$ ) according to $\mathrm{PN}$ ISO 11047:2001. The samples of mixtures of grasses were mineralized at the temperature of about $450^{\circ} \mathrm{C}$ and remains were dissolved in concentrated $\mathrm{HNO}_{3}$ [Filipek et al. 2003].

Plants for the dry matter determination were taken in June, July and September 2012, then they were dried in an oven at $105{ }^{\circ} \mathrm{C}$ for $24 \mathrm{~h}$, then at 
$75^{\circ} \mathrm{C}$ until complete evaporation of water. Bioconcentration factors (BCF) for analyzed heavy metals were determined as quotients of average concentration of a given element in plants with relation to its average concentration in soil. The correlation between heavy metals concentration in above ground of plants and in soil fertilized with different doses of sewage sludge were calculated using Spearman's correlation factor $r$ for $\mathrm{p} \leq 0.05$ by using Statistica 10.0.

\section{RESULTS AND DISCUSION}

Białystok Wastewater Treatment Plant operates as an important element of the Polish Green Lungs. It is one of the ten largest sewage treatment plants in Poland. It was opened in 1994. Designed for the capacity of $176500 \mathrm{~m}^{3} / \mathrm{day}$, it turned out to be receiving a much greater amount of actually sewage than it had been planned. Currently, the actual throughput is about 100 thousand $\mathrm{m}^{3} / \mathrm{d}$. It is a mechanical-biological treatment plant with sludge treatment and biogas exploitation. The treatment plant has a modern sanitary sludge treatment, which comprises a sludge dryer which produces granular sludge. These granules were tested and they are suitable for use on all types of soils. It is especially recommended for weak mineral soils with low organic matter content. It can be used in the cultivation of agricultural crops, lawns, squares of green, to fertilize outdoor trees, shrubs and ornamental plants. In the case of the use of dehydrated sludge after the press one must reckon with the possibility of depositing the chemicals in them, and especially

Table 1. Selected physical and chemical properties of soils

\begin{tabular}{|c|c|c|}
\hline \multicolumn{2}{|l|}{ Properties } & $\begin{array}{l}\text { The limits of heavy metals } \\
\text { in the surface of light soil } \\
\text { layer }(0-25 \mathrm{~cm}) \text { with the } \\
\text { application of municipal } \\
\text { sewage sludge for land } \\
\text { reclamation for non-agri- } \\
\text { cultural (Regulation 2010) }\end{array}$ \\
\hline $\mathrm{pH}$ & 7.65 & - \\
\hline Textural class & $\begin{array}{l}\text { loamy } \\
\text { sand }\end{array}$ & - \\
\hline $\mathrm{P}_{2} \mathrm{O}_{5}\left[\mathrm{mg} \times 100 \mathrm{~g}^{-1}\right.$ D.M. $]$ & 14.43 & - \\
\hline Cd [mg/kg D.M.] & $<0.50$ & 3 \\
\hline $\mathrm{Cu}$ [mg/kg D.M.] & 17.35 & 50 \\
\hline $\mathrm{Pb}$ [mg/kg D.M.] & 25.2 & 50 \\
\hline Zn [mg/kg D.M.] & 138.95 & 150 \\
\hline
\end{tabular}

dangerous organisms from a sanitary point of view. Some amount of impurities coming to the wastewater treatment plant is decomposed in the biological treatment processes, some importing impurities accumulate in sludge formed in the purifying processes and some are discharged with wastewater to the receiver. The content of toxic substances, heavy metals and biological contamination, depends on the amount and type of waste taken to the municipal sewer system. For the most part of sludge, the amount of these impurities is small and does not pose a serious risk to health and environment [Bernacka, Pawłowska 2000, Fukas-Płonka 2011].

Before the onset of the experiment both sewage sludge and soil from each combination were analyzed according to the Resolution of Ministry of Environment of July $13^{\text {th }}, 2010$ concerning municipal sewage sludge. The analyses were done by the Regional Chemical and Agricultural Station in Białystok (Table 1 and 2). Additionally, soil $\mathrm{pH}$ in $1 \mathrm{M} \mathrm{KCl}$ were determined. Biological and parasitological indications were conducted in the Division of Sanitary Biology and Biotechnology, Białystok University of Technology. The results are shown in Tables 1 and 2. According to the cited Regulation, the tested samples from sewage sludge treatment plant in Białystok and averaged soil samples taken from the top layer of plots met all the criteria set out in the Regu-

Table 2 Selected properties of municipal sewage sludge

\begin{tabular}{|c|c|c|}
\hline Properties & Granular sludge & $\begin{array}{l}\text { Dehydrated } \\
\text { sludge }\end{array}$ \\
\hline $\mathrm{pH}$ & 7.6 & 7.4 \\
\hline Dry weight (\%) & 88 & 19.8 \\
\hline Organic matter (\% D.W.) & 59.2 & 58.4 \\
\hline Total P (\% D.W.) & 3.2 & 3.0 \\
\hline Total N (\% D.W.) & 4.6 & 4.4 \\
\hline Ammonium N (\% D.W.) & 0.32 & 0.2 \\
\hline Ca (\% D.W.) & 4.1 & 4.6 \\
\hline Mg (\% D.W.) & 0.7 & 0.6 \\
\hline $\mathrm{Pb}\left(\mathrm{mg} \times \mathrm{kg} \mathrm{D} . \mathrm{W}^{-1}\right)$ & 21.9 & 20.7 \\
\hline $\mathrm{Cd}\left(\mathrm{mg} \times \mathrm{kg}\right.$ D.W. $\left.{ }^{-1}\right)$ & 1.2 & $<1.26$ \\
\hline $\mathrm{Cu}\left(\mathrm{mg} \times \mathrm{kg} \mathrm{D} . \mathrm{W} .^{-1}\right)$ & 208 & 179 \\
\hline $\mathrm{Zn}\left(\mathrm{mg} \times \mathrm{kg} \mathrm{D} . \mathrm{W} .^{-1}\right)$ & 1109 & 1208 \\
\hline $\begin{array}{l}\text { The number of viable } \\
\text { helminth ova of Ascaris } \\
\text { sp., Trichris sp., } \\
\text { Toxocara sp. }\end{array}$ & Not detected & Not examinated \\
\hline $\begin{array}{l}\text { Bacteria of the genus } \\
\text { Salmonella in } 100 \mathrm{~g} \text { of } \\
\text { sludge }\end{array}$ & Not detected & Not examinated \\
\hline
\end{tabular}


lation. Dehydrated sludge from the press did not contain Salmonella and invasive nematode ova. In the case of granules, it was not necessary to do biological studies, because sewage sludge was dried at $130{ }^{\circ} \mathrm{C}$.

Basing on the results, it was possible to use both types of deposits in the later part of the experiment and the establishment of the experimental plots.

Grassy areas in the passageways are usually established on degraded soils characterized by a mechanical malfunction and poor trophic conditions. Before the introduction of plants or at the stage of change of land use, soils often require the enrichment with organic substance to improve the physical and chemical properties, to provide a source of macro- and micronutrients, and to accelerate positive biological changes [Karczewska et al. 2012]. However, psychological barrier associated with the source of their origin, the specific structure of the sediment and usually a high content of certain heavy metals make it very difficult to find a buyer who could reasonably use sewage sludge [Dmochowski et al. 2011].

Heavy metals are not broken down by microorganisms in the biological treatment of wastewater. The soluble form is especially toxic, as it is generally found in plants and animals and can bioaccumulate in these organisms, as well as in humans. Moreover, heavy metals are involved in many chemical reactions. They can change forms from a soluble to insoluble state and from an absorbed to a free state [Zhu, Zang 2001]. The dynamics of changes in forms of metals is most intense in the top layer of the soil and it depends on diverse populations of microorganisms, content of organic matter, cation exchangeable capacity (CEC) and the biological interaction associated with microorganisms activity of rhizosphere and also on the plant itself [Adriano et al. 2004]. In our study, the content of metals was examined in plant, which grew on plots where different kinds and various doses of sewage sludge and sludge with EM were applied. There were significant correlations between concentrations of metals in the soil and the metal content in the aerial parts of lawn grasses. There was a negative correlation between the content of $\mathrm{Zn}$ in soil fertilized with sludge from the press and $\mathrm{Cu}$ in plants $(\mathrm{r}=-0.82)$, while for the plots fertilized with sludge granules there was also a correlation between $\mathrm{Zn}$ and $\mathrm{Cu}$ in the soil and in plants $(\mathrm{r}=0.88)$. The correlation analysis was also done for press sludge and granulated sludge with the addition of EM. There were significant correlations between concentrations of metals in the soil and the metal content in plants. There was a positive correlation between high lead content in soil fertilized with sludge from the press and $\mathrm{Cd}$ in soil - for these elements at the level of correlation was $r=0.94$ at $p<0.05$.

The fertilization sludge from the press in the dose of $10 \mathrm{~kg} / \mathrm{m}^{2}$ was used, one observed an increased accumulation of the metals in above ground parts of plants about $70 \%$ in the plants with $51 \mathrm{EM} / \mathrm{m}^{2}$ compared with plots with sludge but without EM. In turn, the fertilization with granular sludge and $51 \mathrm{EM} / \mathrm{m}^{2}$ resulted in a lower content of heavy metals in above ground parts of plants, which shows that the sediment from the press plants have more phytoremediation properties than sludge granules. In addition, applying EM into the soil with the sludge from the press led to the strengthening of this effect (Table 3).

The differentiation of geochemical background in Poland is mainly related to variable chemical composition of the rocks from which they arise. Against this background a number of regional and local anomalies of geological and

Table 3. Contents of heavy metals and dry matter of grasses fertilized with different doses of sludge with or without EM

\begin{tabular}{|c|c|c|c|c|c|c|c|c|c|c|}
\hline \multirow{3}{*}{$\begin{array}{l}\text { Dose of sewage } \\
\text { sludge }\end{array}$} & \multicolumn{2}{|c|}{$\mathrm{Cd}[\mathrm{mg} / \mathrm{kg}]$} & \multicolumn{2}{|c|}{$\mathrm{Cu}[\mathrm{mg} / \mathrm{kg}]$} & \multicolumn{2}{|c|}{$\mathrm{Pb}[\mathrm{mg} / \mathrm{kg}]$} & \multicolumn{2}{|c|}{$\mathrm{Zn}[\mathrm{mg} / \mathrm{kg}]$} & \multicolumn{2}{|c|}{ Dry matter $\left[\mathrm{g} / \mathrm{m}^{2}\right]$} \\
\hline & \multicolumn{10}{|c|}{ Dose of EM $\left[1 / \mathrm{m}^{2}\right]$} \\
\hline & 0 & 5 & 0 & 5 & 0 & 5 & 0 & 5 & 0 & 5 \\
\hline $0\left[\mathrm{~kg} / \mathrm{m}^{2}\right]$ & 0.25 & 0.16 & 12.1 & 9.4 & 5.67 & 2.80 & 79.92 & 83.18 & 367.5 & 755.0 \\
\hline \multicolumn{11}{|c|}{ Dehydrated sludge FROM THE PRESS } \\
\hline $5\left[\mathrm{~kg} / \mathrm{m}^{2}\right]$ & 0.19 & 0.25 & 17.5 & 21.05 & 3.57 & 5.03 & 109.245 & 144.96 & 1277.0 & 1391.5 \\
\hline $10\left[\mathrm{~kg} / \mathrm{m}^{2}\right]$ & 0.24 & 0.35 & 21.25 & 30.7 & 5.16 & 6.80 & 134.575 & 171.03 & 1108.5 & 1496.5 \\
\hline \multicolumn{11}{|c|}{ Granular sludge } \\
\hline $1.5\left[\mathrm{~kg} / \mathrm{m}^{2}\right]$ & 0.17 & 0.18 & 16.6 & 13.9 & 2.23 & 2.14 & 102.75 & 81.22 & 901.0 & 1327.0 \\
\hline $3\left[\mathrm{~kg} / \mathrm{m}^{2}\right]$ & 0.18 & 0.19 & 16.3 & 15.7 & 2.43 & 2.93 & 106.39 & 87.63 & 977.0 & 766.0 \\
\hline
\end{tabular}


anthropogenic origin can be distinguished [Lis, Pasieczna 1995]. The sequence of heavy metal concentration $(\mathrm{mg} / \mathrm{kg})$ in the meadow soils in this research was: $\mathrm{Zn}>\mathrm{Cu}>\mathrm{Pb}>\mathrm{Cd}$. The content of cadmium in the soil on the test plots ranged from 0.26 to $0.67 \mathrm{mg} / \mathrm{kg} \mathrm{d.m}$., when the natural values of cadmium specific to Podlasie is $\mathrm{Cd}$ $<0.5$ ppm [Lis, Pasieczna 1995]. The addition of EM reduced the quantity of cadmium in the soil, which may be due to the properties of the sludge and its greater availability to plants. At 5 $\mathrm{kg} / \mathrm{m}^{2}$ sludge from the press and with addition of $51 \mathrm{EM} / \mathrm{m}^{2}$, the amount of Cd decreased from 0.47 to $0.32 \mathrm{mg} / \mathrm{kg}$ d.m., whereas at $10 \mathrm{~kg} / \mathrm{m}^{2}$ of sediment from the press and with the addition of 51 $\mathrm{EM} / \mathrm{m}^{2}$ it decreased from 0.33 to $0.26 \mathrm{mg} / \mathrm{kg}$ d.m. The treatments applied in granular sludge with the addition of $51 \mathrm{EM} / \mathrm{m}^{2}$ resulted in an increase of cadmium in the soil. The granular sludge decomposed more slowly and metals contained in the sediment were gradually released into the soil, hence their less uptake by plants and higher content in the soil. Fertilizing plots with granular sludge in an amount of $1.5 \mathrm{~kg} / \mathrm{m}^{2}$ and a precipitate containing $51 \mathrm{EM} / \mathrm{m}^{2}$ increased the value respectively from 0.37 to $0.45 \mathrm{mg} / \mathrm{kg}$ dry matter, and with $3 \mathrm{~kg} / \mathrm{m}^{2}$ granular sludge with the addition of $51 \mathrm{EM} / \mathrm{m}^{2}$ respectively 0.31 to $0.41 \mathrm{mg} / \mathrm{kg} \mathrm{d} . \mathrm{m}$. (Table 4).

The content of copper in the soils was very diverse (from 6.20 to $27.6 \mathrm{mg} / \mathrm{kg}$ d.m.). The average copper content was located within the natural values of this element in soils for Podlasie region in Poland (20-40 ppm) [Lis, Pasieczna 1995]. The content of zinc in soils varied between 47,60 and $110,76 \mathrm{mg} / \mathrm{kg}$ d.m. with the natural values set at 25-400 ppm Zn, but the content of lead on the test plots where sludge from the press and granular were applied and EM were added to both kinds, was below the natural range of $12.5-100 \mathrm{ppm} \mathrm{Pb}$ given by Lis and Pasieczna [1995] (Table 4).

The $\mathrm{pH}$ is an important factor determining the solubility of heavy metals in soil. It depends on e.g. ion balance - sorption and desorption processes of hydrogen cations and metal cations. Generally, heavy metals solubility is low in the neutral and alkaline range of $\mathrm{pH}$ and increases with decreasing $\mathrm{pH}$ [Kabata-Pendias, Pendias 1999]. Rosada's [2007] studies confirm that the soil $\mathrm{pH}$ determines the uptake of metals by plants and their mobility in the soil. There was no significant correlation between the content of the investigated metals in soil and plants and in soil $\mathrm{pH}$

Trace metals are characterized by a very long period of persistence in the environment. Once entered, they practically remain in the environment and can cause bioaccumulation in the plants and can enter different biological metabolic pathways. Some heavy metals in trace amounts are essential to life but their excess has a negative impact on the health of plants, animals and humans [Bernacka, Pawłowska 2000]. In addition, the mobility of metals plays an important role in the rhizosphere compartment, which corresponds to the whole interface between roots and soil, where interactions between the soil microorganisms, roots and soil constituents take place [Kabata-Pendias, Pendias 1999, Lin et al. 2004]. The release of protons, exudates and metabolites into the rhizosphere by the roots and the microorganisms can modify the $\mathrm{pH}$, depending on the available source of nitrogen nutrients or iron deficiency [Singh et al. 2009, Węglarzy 2007], thus modifying the fixation and mobility of heavy metals in soils [Lin et al. 2004]. The degree of bioaccumulation of a metal is the result of balance between the input rate and the rate of elimination. Bioaccumulation occurs primarily due to the inability to excrete necessary

Table 4. Effects of fertilizing with different doses of sewage sludge with or without EM on soil $\mathrm{pH}$ and contents of heavy metals in soil

\begin{tabular}{|c|c|c|c|c|c|c|c|c|c|c|}
\hline \multirow{3}{*}{$\begin{array}{l}\text { Dose of sewage } \\
\text { sludge }\end{array}$} & \multicolumn{2}{|c|}{$\mathrm{pH}_{\mathrm{KCl}}$} & \multicolumn{2}{|c|}{$\mathrm{Cd}[\mathrm{mg} / \mathrm{kg}]$} & \multicolumn{2}{|c|}{$\mathrm{Cu}[\mathrm{mg} / \mathrm{kg}]$} & \multicolumn{2}{|c|}{$\mathrm{Pb}[\mathrm{mg} / \mathrm{kg}]$} & \multicolumn{2}{|c|}{$\mathrm{Zn}[\mathrm{mg} / \mathrm{kg}]$} \\
\hline & \multicolumn{10}{|c|}{ Dose of EM $\left[1 / \mathrm{m}^{2}\right]$} \\
\hline & 0 & 5 & 0 & 5 & 0 & 5 & 0 & 5 & 0 & 5 \\
\hline $0\left[\mathrm{~kg} / \mathrm{m}^{2}\right]$ & 7.20 & 7.06 & 0.67 & 0.30 & 27.60 & 12.60 & 12.98 & 7.78 & 110.76 & 47.60 \\
\hline \multicolumn{11}{|c|}{ Dehydrated sludge from the press } \\
\hline $5\left[\mathrm{~kg} / \mathrm{m}^{2}\right]$ & 7.22 & 7.06 & 0.47 & 0.32 & 17.35 & 8.15 & 10.86 & 8.53 & 80.94 & 48.02 \\
\hline $10\left[\mathrm{~kg} / \mathrm{m}^{2}\right]$ & 7.23 & 6.96 & 0.33 & 0.26 & 18.80 & 6.20 & 7.58 & 9.25 & 61.03 & 46.23 \\
\hline \multicolumn{11}{|c|}{ Granular sludge } \\
\hline $1.5\left[\mathrm{~kg} / \mathrm{m}^{2}\right]$ & 7.03 & 7.18 & 0.37 & 0.45 & 12.75 & 13.20 & 8.45 & 12.25 & 64.34 & 63.38 \\
\hline $3\left[\mathrm{~kg} / \mathrm{m}^{2}\right]$ & 7.23 & 7.15 & 0.31 & 0.41 & 7.15 & 8.55 & 7.98 & 9.76 & 43.94 & 67.96 \\
\hline
\end{tabular}


levels of the contaminant [Kabata-Pendias, Pendias 1999, Malik et al. 2010].

According to Wilk and Gworek [2009], cadmium has affinity for any components of sewage sludge and is relatively readily soluble, so that plants absorb it proportionally to the concentration of this element in environment regardless of the $\mathrm{pH}$ of soil. In our study, BCF for $\mathrm{Cd}$ (Figure 1) was the highest (on average of about 1.13) at the highest dose on applied sewage sludge $\left(10 \mathrm{~kg} / \mathrm{m}^{2}\right)$ from press with $51 \mathrm{EM} / \mathrm{m}^{2}$, while the lowest for control plots (0.37). The applied sludge from the press and the granules increased cadmium BCF in the aboveground parts of grass proportionally to the dose of biosolids. The addition of EM to sewage sludge increased the contend of $\mathrm{Cd}$ in plants in the plots with sludge from press, while in the plots with granules the BCF of cadmium in aboveground part of grasses was lower $(0.42$ and 0.47 respectively for plots with 1.5 and $3 \mathrm{~kg} /$ $\mathrm{m}^{2}$ dose of biosolids with $51 \mathrm{EM} / \mathrm{m}^{2}$ ). Lead like cadmium is an element which is not required for the growth and development of plants. The BCF of $\mathrm{Pb}$ in this study was in the range of $0.17-0.74$. One observed increased BCF in samples collected from plots where biosolids from the press with $51 \mathrm{EM} / \mathrm{m}^{2}$ were applied, while in the plots with granular sludge the BCF decreased.

Zinc and copper are microelements that are the most mobile in soil, accumulate in the upper layers of soil and they are readily soluble and available to plants [Węglarzy 2007]. In our study the BCF of $\mathrm{Cu}$ and $\mathrm{Zn}$ in the plots fertilized with sludge from press and granules sludge were in the range from 1.01 to 2.28 for $\mathrm{Cu}$ and from 1.35 to 2.42 for $\mathrm{Zn}$. The addition of EM caused an increase of BCF in plots with sewage sludge from press in comparison with a pure sewage sludge without EM by $150 \%$ at dose of $5 \mathrm{~kg} /$ $\mathrm{m}^{2}$, by $330 \%$ at dose of $10 \mathrm{~kg} / \mathrm{m}^{2}$ for copper, by $120 \%$ for single sewage sludge dose and by $60 \%$ at double dose of sludge for zinc. According to Węglarzy [2007], copper is hardly released from the soil, plants accumulate it mainly in roots but in contaminated environment its concentration increases in aboveground parts of plant. BCF of $\mathrm{Cu}$ and $\mathrm{Zn}$ decreased when sewage sludge with EM was used (Figure 1).

\section{CONCLUSION}

1. The fertilization of soil with sewage sludge from Municipal Wastewater Treatment Plant in Białystok at 5 and $10 \mathrm{~kg} / \mathrm{m}^{2}$ had a positive effect on the growth of lawn grasses biomass.

2. The use of sludge from the press and in a form of concentrated granules usually did not significantly affect the content of heavy metals both in the grass and in the soil.

3. The addition of EM to dewatered sludge from the press significantly decreased the content of heavy metals in the soil, and thus contributed to increase their absorption by plants. This resulted in the improvement of lawn grass remediation capacity for $\mathrm{Cd}, \mathrm{Cu}, \mathrm{Pb}$ and $\mathrm{Zn}$.

4. The precipitate in the form of granules with addition of EM contributed to increased concentration of heavy metals in the soil and thus to the reduction of these metals in aboveground parts of plants.

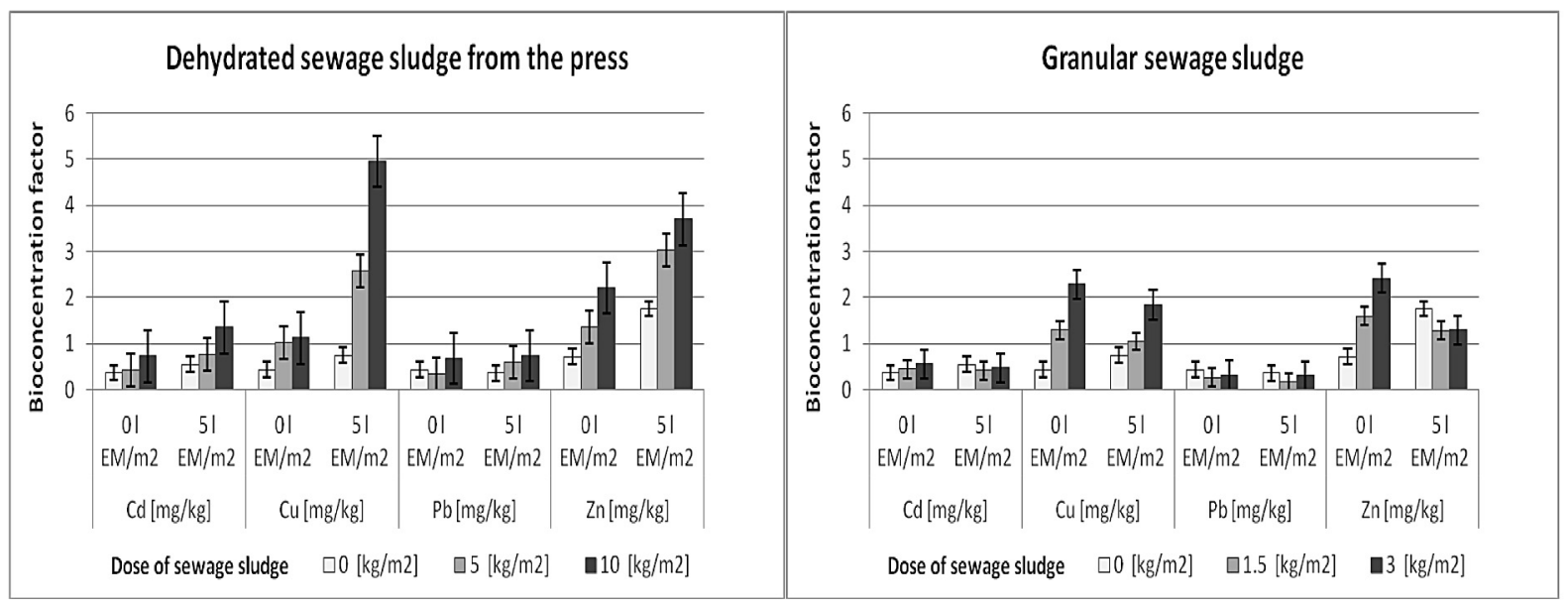

Figure 1. BCF of heavy metals $(\mathrm{Cd}, \mathrm{Cu}, \mathrm{Pb}$ and $\mathrm{Zn})$ in lawn grasses depending on the dose and kind of sewage sludge with or without EM 
5. BCF of heavy metals in plants was characterized by high variability, depending on the type of sediment and the addition of EM.

\section{Acknowledgments}

The research presented was supported financially by the project $\mathrm{S} / \mathrm{WBiIS} / 3 / 2011$ and $\mathrm{W} /$ WBiIŚ/14/2014.

\section{REFERENCES}

1. Adriano D.C., Wenzel W.W., Vangronsveld J., Bolan N.S. 2004. Role of assisted natural remediation in environmental cleanup. Geoderma., 122, 121-142.

2. Alvarez E.A., Mochón M.C., Jiménze Sánchez J.C., Rodríguez M.T. 2002. Heavy metal extractable forms in sludge form wastewater treatment plants. Chemosphere, 47, 765-775

3. Bernacka J., Pawłowska L., 2000. Potentially toxic substances in sludge from municipal wastewater treatment. Wyd. IOŚ, Warszawa, 7-9.

4. Butarewicz A. 2013. Pathogenic organisms in sewage sludge - the detection and neutralization. The Publishing House of Bialystok University of Technology.

5. Dmochowski D., Gajkowska-Stefańska L., Dmochowska A., Presnarowicz R.K. 2011. Application of heavy metals speciation in assessing suitability of municipal post-fermentation sludge for producing roll-out grass. Prz. Nauk. Inż. Kszt. Środ., 53, 207-216.

6. Filipek T.A., Kaczor A., Badora A. 2003. Fundamentals and effects of chemicals in agroecosystems. Akademia Rolnicza, Lublin.

7. Fukas-Płonka Ł. 2011. Management of sewage sludge. Selected issues. Pol. Zrzeszenie Inżynierów i Techników Sanitarnych. Oddz. Wielkopolski. Poznań.

8. Gawroński S.W. 2009. Fitoremediacja a tereny zieleni. Zieleń Miejska, 10, 31.

9. Kabata-Pendias A., Pendias H. 1999. Biogeochemistry of trace elements, Państwowe Wydawnictwo Naukowe, Warszawa.

10. Karczewska A., Gersztyn L., Gałka B. 2012. The effects of various kinds of sewage sludge applied to soil on the amounts of soluble copper forms in polluted soils. Ochr. Środ. i Zasob. Natur., 51, 53-61.
11. Khaliq A, Abbasi MK, Hussain T. 2006. Effects of integrated use of organic and inorganic nutrient sources with effective microorganisms (EM) on seed cotton yield in Pakistan. Biores. Tech., 97, 967-972.

12. Lin Q., Chen Y.X., He Y.F., Tian G.M. 2004. Rootinduced changes of lead availability in the rhizosphere of Oryza sativa L. Agr. Ecosyst. Environ., 104, 605-610.

13. Lis J., Pasieczna A. 1995. Geochemical atlas of Poland. Warszawa.

14. Pathak A., Dastidar M.G., Sreekrishnan T.R. 2009. Bioleaching of heavy metals from sewage sludge: A review. J. Environ Manage., 90(8), 2343-2353.

15. Paz-Ferreiro J., Gascó G., Gutiérrez B., Méndez A. 2012. Soil biochemical activities and the geometric mean of enzyme activities after application of sewage sludge and sewage sludge biochar to soil. Biol Fertil Soils., 48, 511-517.

16. PN-ISO 11047:2001. Soil quality. Determination of $\mathrm{Cd}, \mathrm{Cr}, \mathrm{Co}, \mathrm{Cu}, \mathrm{Pb}, \mathrm{Mn}, \mathrm{Ni}$ and $\mathrm{Zn}$ in extracts with aqua regia. Methods of flame and electrothermal atomic absorption spectroscopy.

17. Rosada J. 2007. Ekologiczne aspekty wykorzystania obszarów objętych oddziaływaniem emisji hut miedzi do upraw rolniczych. Postępy w Ochronie Roślin, 47(1), 119-127.

18. Singh A., Kuhad R.C., Ward O.P. 2009. Advances in applied bioremediation. Soil Biology 17, Springer-Verlag Berlin Heidelberg.

19. Skoczko I., Piekutin J. 2014. Photo-Fenton method usage to organic compounds degradation. Desalin. Water Treat. 52, 19-21.

20. Malik R.N., Husain S.Z., Nazir I. 2010. Heavy metal contamination and accumulation in soil and wild plant species from industrial area of Islamabad. Pakistan. Pak. J. Bot., 42(1), 291-301.

21. Węglarzy K. 2007. Heavy metals - a source of contamination and environmental impact. Wiad. Zootech., 45(3), 31-38.

22. Weiner R.F., Matthews R.A. 2003. Environmential Engineering, Elsevier Science, Burlington.

23. Wilk J., Wolańczyk F. 2008. Problems of the energy utilization of the waste from the sewage-treatment plant. Polityka Energetyczna, 11(2), 139-149.

24. Wilk M., Gworek B. 2009. Heavy metals in sewage sludge. Ochr. Środ. i Zasob. Natural., 39, 40-59.

25. Zhu S Q, Zang X P. 2001. On heavy metal pollution along Yangtze River stretches of urban areas in major cities. Yangtze River, 32(7), 23-25. 